\title{
The 7-13 March 2006 major Saharan outbreak: Multiproxy characterization of mineral dust deposited on the West African margin
}

\author{
C. Skonieczny, ${ }^{1}$ A. Bory, ${ }^{1}$ V. Bout-Roumazeilles, ${ }^{1}$ W. Abouchami, ${ }^{2}$ S. J. G. Galer ${ }^{2}$ \\ X. Crosta, ${ }^{3}$ J.-B. Stuut, ${ }^{4,5}$ I. Meyer, ${ }^{5}$ I. Chiapello, ${ }^{6}$ T. Podvin, ${ }^{6}$ B. Chatenet, ${ }^{7,8}$ A. Diallo, ${ }^{9}$ \\ and T. Ndiaye ${ }^{9}$
}

Received 2 May 2011; revised 29 June 2011; accepted 8 July 2011; published 29 September 2011.

[1] Mineral dust deposits were collected at Mbour, Senegal, throughout the spring of 2006 and especially during the well-documented March 7-13 large Saharan dust outbreak. During this 7-day period, significant changes in mass flux, grain-size, clay mineralogy and $\mathrm{Sr}$ and $\mathrm{Nd}$ isotopic compositions were recorded, indicating distinct provenances for the dust transported and deposited during and outside the event. All these terrigenous proxies, as well as freshwater diatom taxa, also showed significant temporal variations during the outbreak, implying contributions from at least two different provenance regions. Tri-dimensional back-trajectories and satellite imaging enabled us to link those distinct signatures to regions increasingly to the southeast within a large area covering Mauritania, Mali and southern Algeria, identified by the Total Ozone Mapping Spectrometer (TOMS) as the main source of the prominent winter/spring plume over the tropical Atlantic. The multiproxy characterization of the March 7-13 dust fall therefore enables us to typify the terrigenous signature of two different regions supplying dust off West Africa, and provide valuable clues for the interpretation of Northeastern Tropical Atlantic Ocean dust sedimentary records in terms of changes in provenance regions and transport systems. Additionally, because dust deposition data are scarce, flux and grain size data obtained in this study, among other parameters such as clay assemblages, provide important constraints for atmospheric transport models and dust deposition budget estimates in this area.

Citation: Skonieczny, C., et al. (2011), The 7-13 March 2006 major Saharan outbreak: Multiproxy characterization of mineral dust deposited on the West African margin, J. Geophys. Res., 116, D18210, doi:10.1029/2011JD016173.

\section{Introduction}

[2] It is well established that wind-blown mineral dust plays an active role in the Earth climate system [e.g., Maher et al., 2010]. During its transport, dust modifies scattering and absorption properties of the atmosphere as well as cloud characteristics [Sassen et al., 2003], ultimately affecting the

\footnotetext{
${ }^{1}$ Geosystemes, FRE CNRS 3298, Université Lille1, Villeneuve d’Ascq, France.

${ }^{2}$ Max Planck Institute for Chemistry, Mainz, Germany.

${ }^{3}$ EPOC, UMR CNRS 5805, Université Bordeauxl, Talence, France.

${ }^{4}$ Marine Geology, Royal Netherlands Institute for Sea Research, Den Burg, Netherlands.

${ }^{5}$ MARUM, University of Bremen, Bremen, Germany.

${ }^{6}$ LOA, UMR CNRS 8518, Université Lille1, Villeneuve d'Ascq, France.

${ }^{7}$ LISA, UMR CNRS 7583, Universités Paris Est-Paris Diderot-Paris 7, IPSL, Créteil, France.

${ }^{8}$ IRD/UJF-Grenoble 1, LTHE UMR 5564, Grenoble, France.

${ }^{9}$ IMAGO, US 191, IRD, Dakar, Senegal.

Copyright 2011 by the American Geophysical Union. 0148-0227/11/2011JD016173
}

radiative balance of the Earth and the hydrological cycle [Arimoto, 2001]. Dust may also affect climate indirectly via the boosting of the biological productivity in surface waters in iron-depleted areas [Duce et al., 1991; Martin et al., 1991] and/or of the export of organic matter down the water column, both of which having some impact on the uptake of atmospheric $\mathrm{CO}_{2}$ by marine ecosystems [Bopp et al., 2003]. Yet, despite the potential impact of mineral dust on global climate, dust remains one of the less wellquantified elements of the climate system [Forster et al., 2007].

[3] Dust deposition in particular is poorly constrained. Even in the vicinity of major arid and semi-arid areas, such as the Sahara-Sahel region - the world's largest dust source [Prospero et al., 2002] - there are virtually no data available in the literature. Dust deposition quantification is essential for assessing the role of dust on the ocean realm, however, and for validation of dust transport models [Tegen, 2003]. The characterization of present-day dust deposits signatures may also be useful for the interpretation of the marine sedimentary records, especially in the North Eastern Atlantic Tropical Ocean, where most of the terrigenous fraction is of aeolian origin. 


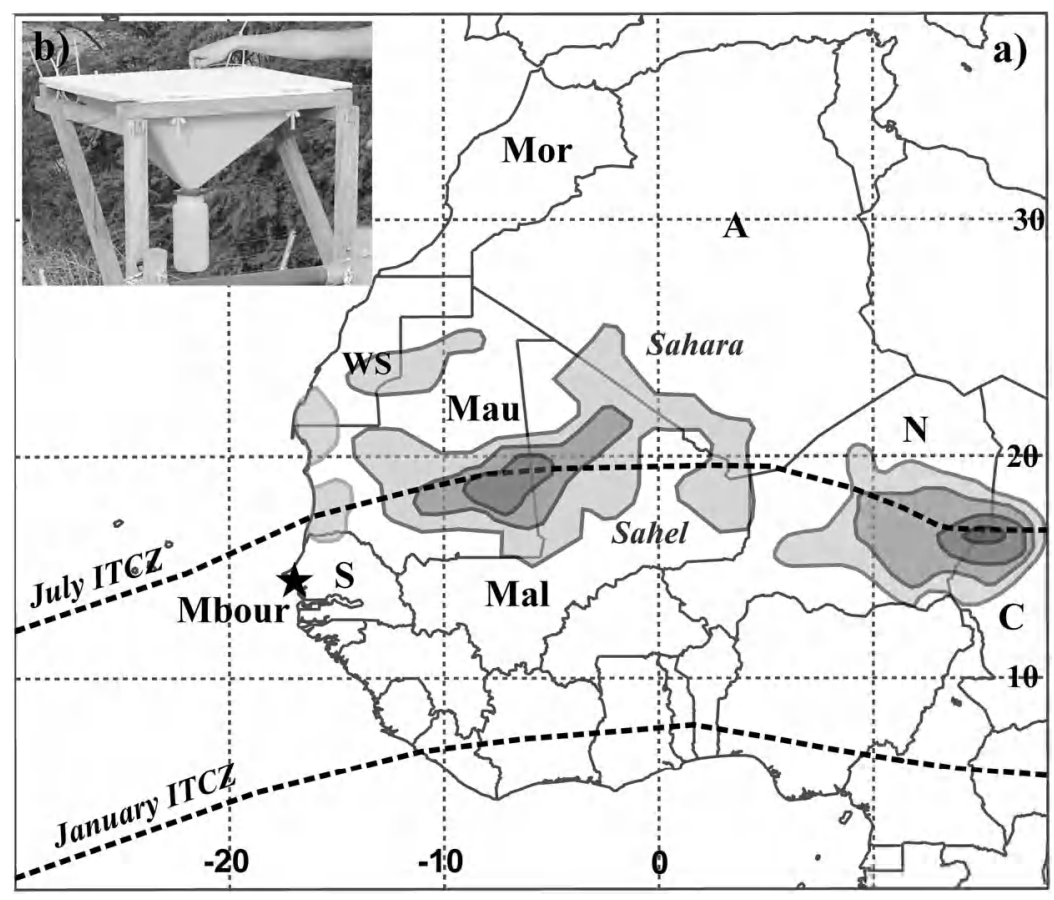

Figure 1. (a) Location of the Mbour site (star). The gray areas represented the $>15$ annual mean Aerosol Index derived from TOMS after Goudie and Middleton [2001]. Dotted lines represent the winter (January) and summer (July) ITCZ position. Countries are distinguished by letters: A (Algeria), C (Chad), Mal (Mali), Mau (Mauritania), Mor (Morocco), N (Niger), S (Senegal), WS (Western Sahara). (b) Picture of our Capyr-type trap.

[4] The African Multidisciplinary Monsoon Analysis (AMMA) field campaign in spring 2006 was partly devoted to improving our current knowledge of the dust particle atmospheric cycle in this region [Redelsperger et al., 2006]. During March 2006, dust activity was very pronounced over a large part of West Africa, and especially throughout the March 7-13 period, when the formation of an intense dust haze was observed over the region [Slingo et al., 2006; Tulet et al., 2008; Thomas and Gautier, 2009]. Here we present a multiproxy characterization of the terrigenous signature of the dust that fell over Mbour, Senegal, during the spring 2006 AMMA field campaign, with focus on the March 7-13 event, which is regarded as a typical example of a winter monsoon season mineral dust event [Derimian et al., 2008; Marticorena et al., 2010].

\section{Methods}

[5] The sampling site was located at the southern end of the city of Mbour ( $~ 80 \mathrm{~km}$ south of Dakar; Figure 1a), on the premises of the Institut de Recherche pour le Développement (IRD) ecological center. It is a vegetated area and car traffic on the site is minimal, reducing any influence from locally produced-dust. Dust was collected using a Capyr-type reversed pyramid-shaped PVC collector [Goossens and Rajot, 2008] installed at about $8 \mathrm{~m}$ above ground on the rooftop terrace of the IRD research building facing the Atlantic Ocean. This collector has the advantage of being made entirely of plastic (Figure 1b), minimizing potential contamination of the dust samples with chemical elements of interest. The original Capyr-type collector, however, has relatively lower efficiency (up to a mean factor of 3 ) than other sampling devices due to its poorer aerodynamic shape [Goossens and Rajot, 2008]. For this reason, the $2500 \mathrm{~cm}^{2}$ sampling area was covered in this study with a $1-\mathrm{cm}$ thick honeycomb-like grid in order to reduce wind turbulence within the collector. This adjustment should have limited post-depositional remobilization, thus improving the collector's efficiency. Dust deposited in the device was recovered weekly from February 23 until May 29, 2006 by thorough rinsing with ultra-pure water. Temporal sampling resolution was increased around the March 7-13 outbreak (Table 1).

[6] Subsequent treatments were carried out in clean laboratory facilities. In order to remove the calcium carbonate component without altering clays, samples were leached using an acetic acid (HOAc) - sodium acetate buffer at $\mathrm{pH}$ $\sim 4.5$ [Biscaye, 1965]. Although there are studies that demonstrate that distal dust can be relatively coarse [e.g., Glaccum and Prospero, 1980], modern dust collected over the Atlantic Ocean at the latitude of our dust collector has been observed to be $<30 \mu \mathrm{m}$ [Stuut et al., 2005]. Therefore, samples were wet-sieved at $30 \mu \mathrm{m}$ in order to prevent contamination by potential large 'local' mineral particles and vegetation detritus. Mass fluxes were calculated for the $<30$ and $<73 \mu \mathrm{m}$ fractions, but all the following analyses were performed on the $<30 \mu \mathrm{m}$ fraction.

[7] Grain-size measurements were carried out using a Malvern Mastersizer 2000 laser diffractometer as described by Sperazza et al. [2004] and the mean modal size was calculated from the volume size distribution of the dust deposits. Semiquantitative clay mineralogical composition 


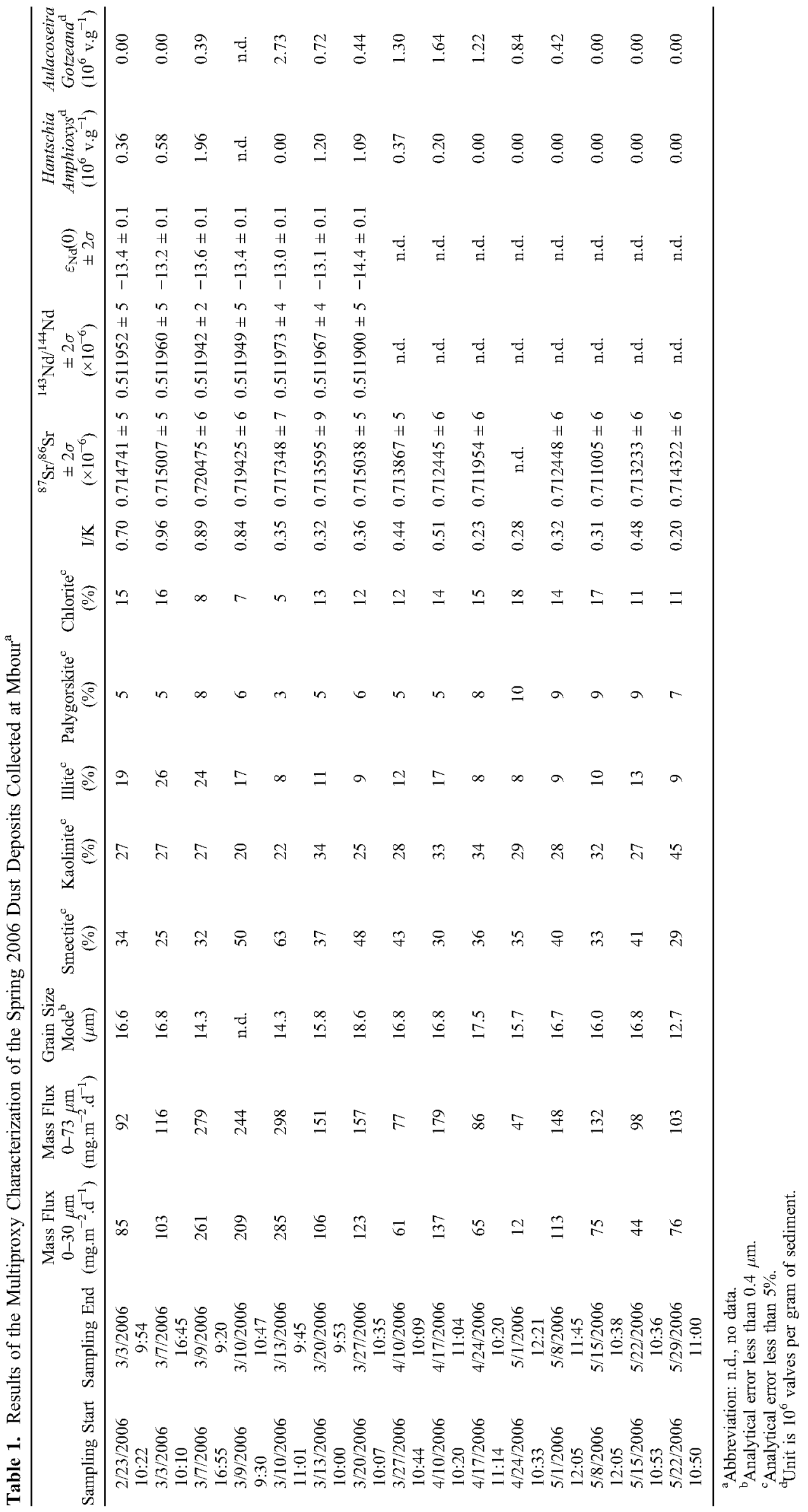


of the dust particles was carried out by X-ray diffraction (XRD). Non-oriented aggregates of the $<30 \mu \mathrm{m}$ carbonatefree fractions were deposited on silicon disks and measured by XRD on a Bruker D4 Endeavor set (with a Lynxeye fast detector; $\mathrm{Cu} X$-ray tube; $30 \mathrm{kV}$ voltage; $30 \mathrm{~mA}$ intensity). Two XRD runs were performed routinely for each sample: (1) air-dried sample, and (2) ethylene-glycol vapor saturation for $12 \mathrm{~h}$. Each clay mineral was characterized as described by Bout-Roumazeilles et al. [1999] and semiquantitative estimation of clay mineral abundances (\%) was performed using the Macintosh MacDiff ${ }^{\circledR} 4.2 .5$ software (R. Petschick, http:// www.geologie.uni-frankfurt.de/Staff/Homepages/Petschick/ RainerE.html).

[8] For strontium ( $\mathrm{Sr}$ ) and neodymium $(\mathrm{Nd})$ isotope analyses, aliquots of about $20 \mathrm{mg}$ were dissolved in PFA Savillex $\mathbb{B}$ beakers using a mixture of hydrofluoric acid (HF) and nitric acid $\left(\mathrm{HNO}_{3}\right)$. Sr and the rare earth elements (REE) were separated using standard cation exchange column chromatography procedures. Nd was purified from the REE fraction by cation exchange using $\alpha$-hydroxyisobutyric acid (HIBA) as eluent. $\mathrm{Sr}$ and $\mathrm{Nd}$ isotopic compositions were measured by Thermal Ionization Mass Spectrometry (TIMS) on a ThermoFisher TRITON at the Max Planck Institute for Chemistry, Mainz, Germany. ${ }^{87} \mathrm{Sr} /{ }^{86} \mathrm{Sr}$ ratios were normalized to ${ }^{86} \mathrm{Sr} /{ }^{88} \mathrm{Sr}=0.1194$ and replicate measurements of the NIST SRM 987 standard yield an average ${ }^{87} \mathrm{Sr} /{ }^{86} \mathrm{Sr}=$ $0.710262\left(2 \mathrm{SD}=8 \times 10^{-6}, \mathrm{n}=19\right) .{ }^{143} \mathrm{Nd} /{ }^{144} \mathrm{Nd}$ ratios were normalized to ${ }^{146} \mathrm{Nd} /{ }^{144} \mathrm{Nd}=0.7219$ and measurements of La Jolla Nd standard yielded ${ }^{143} \mathrm{Nd} /{ }^{144} \mathrm{Nd}=0.511844(2 \mathrm{SD}=$ $\left.5 \times 10^{-6}, \mathrm{n}=8\right)$. The ${ }^{143} \mathrm{Nd}^{144} \mathrm{Nd}$ ratios are reported as $\varepsilon_{\mathrm{Nd}}$, the relative deviation from the Bulk Silicate Earth ${ }^{143} \mathrm{Nd} /{ }^{144} \mathrm{Nd}$ ratio of 0.512638 in parts per 10000 . Analytical blanks were always less than $0.1 \%$ of Sr and $\mathrm{Nd}$ analyzed and can be considered negligible.

[9] Diatom species were identified and counted using a Olympus BX51 phase contrast microscope at a magnification of $\times 1000$ at University Bordeaux-1, France, following procedures described by Rathburn et al. [1997].

\section{Results and Discussion}

\subsection{The 7-13 March 2006 Major Dust Event: The Context Over Mbour}

[10] Westward Saharan dust transport across West Africa and the Northeastern Tropical Atlantic Ocean occurs nearly all year-round but is most prominent through the spring and the summer seasons [Swap et al., 1996]. During the summer, when the ITCZ sits at its northernmost position and the West African monsoon provides rainfall to the Sahel region, dust transport occurs at high altitudes $(5-6 \mathrm{~km})$ in the socalled Saharan Air Layer [Prospero and Carlson, 1981], that is above the trade wind inversion along the African coast where it goes nearly unnoticed at ground level [Bory et al., 2002]. Saharan outbreaks affecting the West African margin and the Northeastern Tropical Atlantic Ocean mainly occur during the winter and spring seasons (November to May), when dust is transported within the Harmattan (i.e., dry, winter monsoon continental trade winds) below 1.5$3 \mathrm{~km}$ altitude [Chiapello et al., 1995]. The position of the low-level dust plume over the Atlantic Ocean moves northward throughout the winter monsoon season following the migration of the ITCZ [Swap et al., 1996]. At the latitude of
Senegal, most dust events are recorded at the beginning of the year, often sweeping large parts of West Africa before reaching the Atlantic Ocean and generally peaking around February-March [e.g., Caquineau et al., 2002; Knippertz and Fink, 2006].

[11] This was the case in 2006: significant dust activity began on March 5 initiated by a cold front in the lee of the Atlas Mountains, and developed further between March 7 and March 13, as the dust haze progressed across West Africa toward the Atlantic Ocean [Slingo et al., 2006; Tulet et al., 2008; Thomas and Gautier, 2009]. During this period, the aerosol optical thickness (AOT) at $440 \mathrm{~nm}$ measured by the Mbour Sun photometer jumped from its background level around 0.5 to values above 2.5 (Figure 2a). The AOT peaked first on March 9, and then again on March 11, implying a two-phased event in the atmospheric column. This was associated with changes in the Ångström exponent $\alpha_{440 / 870}$ (used in this case as an indicator of the particlesizes), which dropped to its lowest level, indicating the presence of a "pure" mineral dust event (i.e., free of black carbon from biomass burning; see Derimian et al. [2008] for details).

[12] On the ground, at the Mbour station, the 7-13 March event led to the highest daily mean atmospheric particulate concentration $(<10 \mu \mathrm{m})$ recorded during the 2006 dry season (Figure 2b), but also the most important of the following three years of monitoring (2006-2008) by Tapered Element Oscillating Microbalance (TEOM) (see Marticorena et al. [2010] for details). As expected, this huge dust outbreak resulted in an important deposition event at our site. The terrigenous deposition flux recorded for the March 713 period averages $250 \mathrm{mg} \cdot \mathrm{m}^{-2} \cdot \mathrm{d}^{-1}$, which represents a $2-$ to threefold increase compared to the mean spring background level (Figure 2b and Table 1). Comparison of the $<30 \mu \mathrm{m}$ fraction and the total $(0-73 \mu \mathrm{m})$ deposition fluxes confirms that most of the dust deposited in this area is $<30 \mu \mathrm{m}$ (Figure 2b). To our knowledge, there are no available deposition data in the literature with which we could compare our results. The deposition fluxes we obtained, however, are of the same order of magnitude as downward lithogenic fluxes in the water column estimated from sediment traps moored in the nearby Northeastern Tropical Atlantic [Ratmeyer et al., 1999; Bory and Newton, 2000; Bory et al., 2002]. Fluxes measured at Mbour, however, are higher, consistent with the fact that the mooring locations are farther afield from the dust sources compared to our site. As indicated by the AOT, two distinct phases were also recorded on the ground, as seen in both atmospheric concentration and deposition flux data.

\subsection{Terrigenous Signature: March 7-13 Dust Event Versus Spring Background}

[13] All dust deposits display a well-sorted unimodal grain-size distribution (Figure 3), which is a well-known characteristic of wind-blown sediments [Krumbein and Pettijohn, 1938]. The 2006 dry season mean modal size ranges from 12.7 to $18.6 \mu \mathrm{m}$ (Figure $2 \mathrm{c}$ and Table 1 ). These values are comparable to those obtained for dust collected off NW Africa (9 to $18 \mu \mathrm{m}$ ) [Stuut et al., 2005]. During the March 7-13 dust event, it is noteworthy that the mode decreased from $\sim 16 \mu \mathrm{m}$ to $\sim 14 \mu \mathrm{m}$, coinciding with a sharp decrease in the local wind intensity (Figure 2c). This 


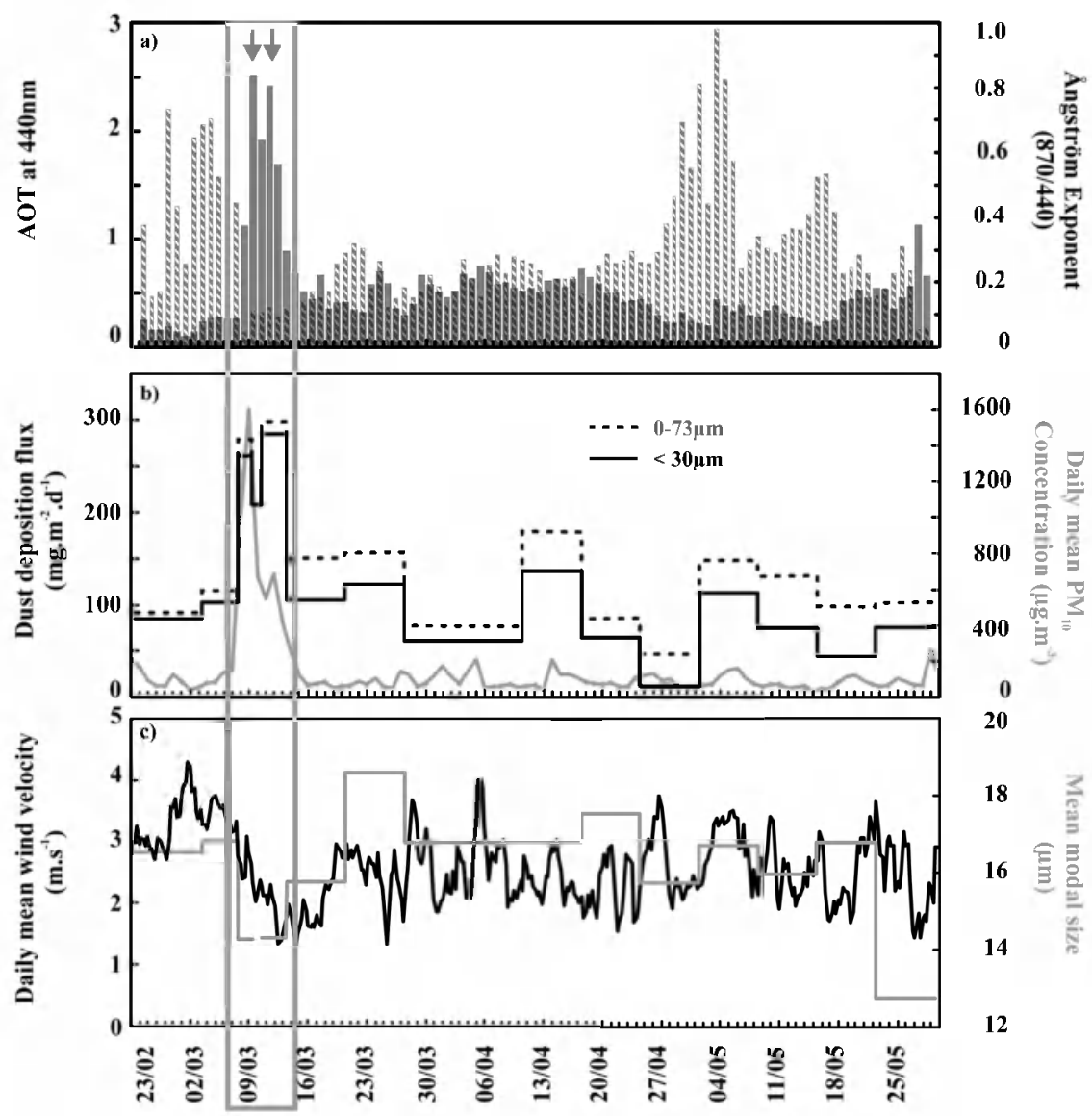

Figure 2. (a) Aerosol optical thickness at $440 \mathrm{~nm}$ (solid bars) and Ångström exponent $\left(\alpha_{440 / 870}\right)$ (dash bars) from Feb. Twenty-three to May 252006 (AERONET database at http://aeronet.gsfc.nasa.gov/). (b) Dust deposition flux: $<73 \mu \mathrm{m}$ (dash line) and $<30 \mu \mathrm{m}$ (solid line) carbonate-free fractions and daily mean $\mathrm{PM}_{10}$ concentration ( $\mu \mathrm{g} . \mathrm{m}^{-3}$ ) [Marticorena et al., 2010]. The gray frame indicates the March 7-13 dust event. (c) Daily mean surface wind velocity $\left(\mathrm{m} . \mathrm{s}^{-1}\right)$ [Marticorena et al., 2010] and mean modal size of the dust deposits.

reduction in air velocity during the event excludes significant local contribution at that time, and must have instead favored deposition of fine aeolian particles transported within the large-scale plume from Saharan-Sahelian sources.

[14] Clay mineralogy and $\mathrm{Sr}$ and $\mathrm{Nd}$ isotopic compositions have been shown to vary with dust provenance, and are therefore useful tracers for source discrimination [Grousset and Biscaye, 2005; Bout-Roumazeilles et al., 2007; Meyer et al., 2011]. Outside the March 7-13 dust event, the clay mineralogy of the dust deposited at Mbour consisted mainly of smectite and kaolinite, with additional contribution of illite, chlorite and palygorskite (Table 1). During the March 7-13 outbreak, there was a significant increase in smectite, with proportions rising above $60 \%$ (Figure 4a). There was also an important change in the ratio between illite and kaolinite (I/K), which reached 0.9 compared to a background range of $0.2-0.5$ for the rest of the sampling period (Table 1). These changes in the mineralogical composition of the dust were accompanied by a marked shift in $\mathrm{Sr}$ isotopic composition. The ${ }^{87} \mathrm{Sr} /{ }^{86} \mathrm{Sr}$ ratios suddenly became more radiogenic during the March 713 event, with measured values up to 0.720 (Figure 4b). By contrast, the ${ }^{87} \mathrm{Sr} /{ }^{86} \mathrm{Sr}$ ratios background remained within

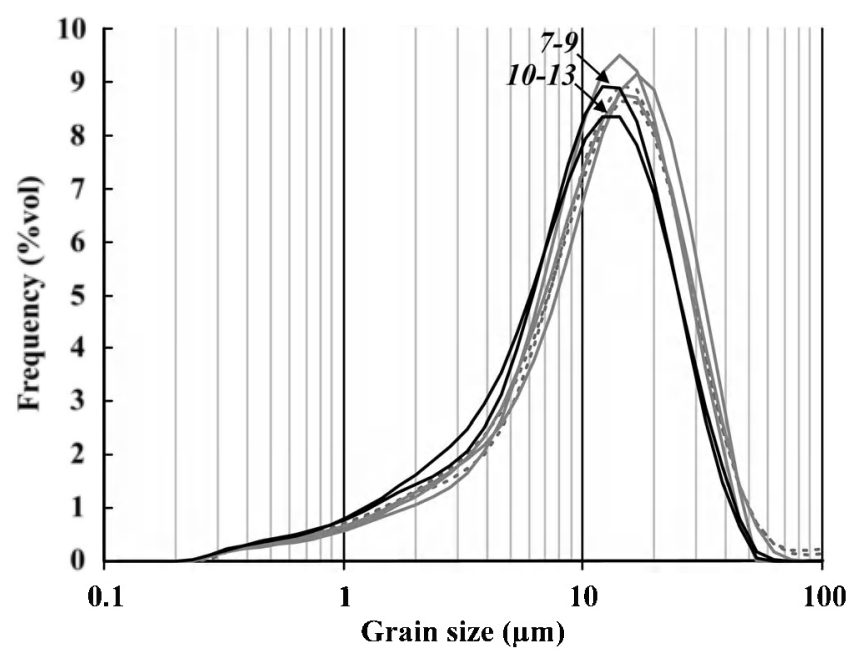

Figure 3. Comparison of grain-size distributions of mineral dust deposited in the sediment trap before the event (dashed gray lines), during the event (dark lines) and after the event (gray lines). 


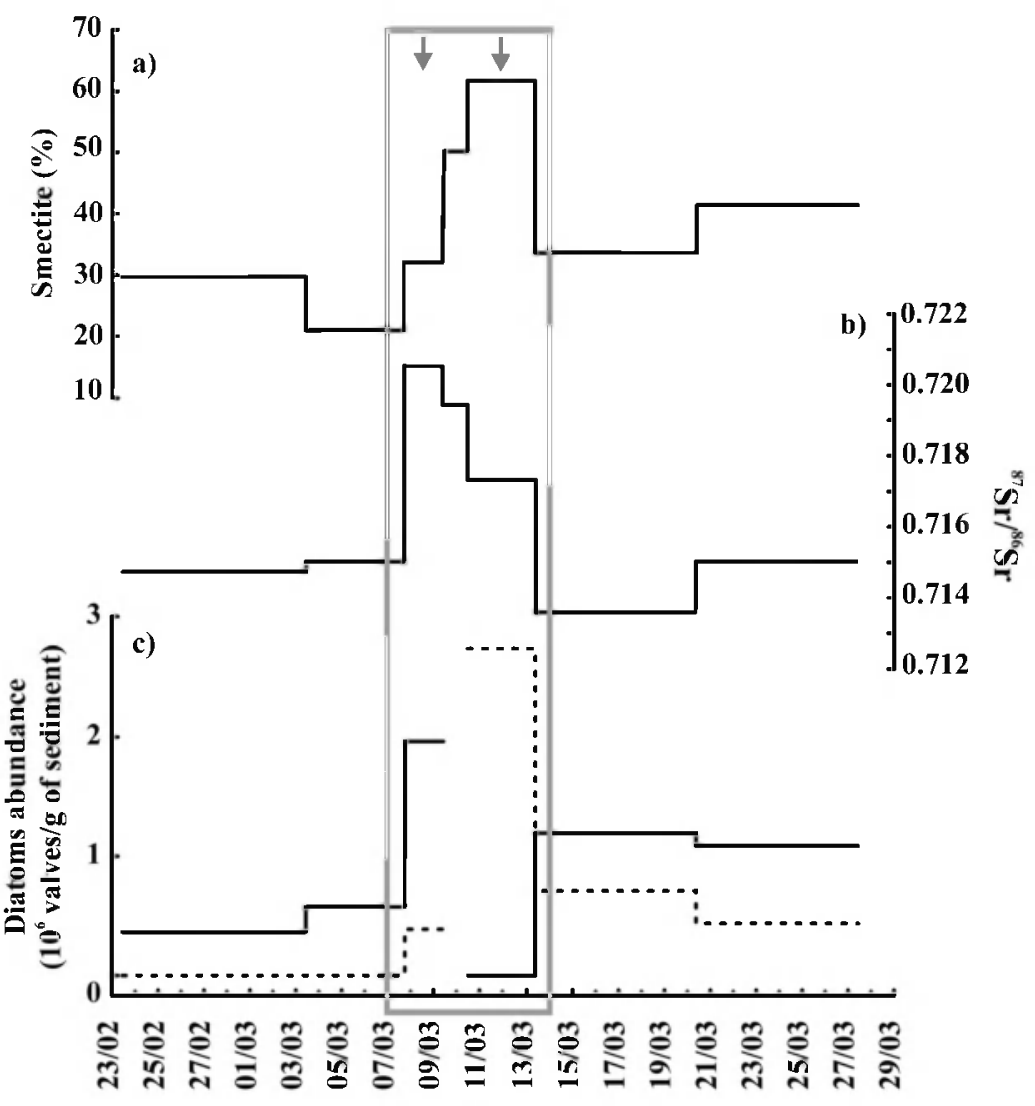

Figure 4. (a) Smectite content (\%) and (b) ${ }^{87} \mathrm{Sr}{ }^{86} \mathrm{Sr}$ ratio of the dust deposits throughout the March 713 event 2006. (c) Fresh-water diatoms Hantzshia amphioxys (solid line) and Aulacoseira granulata/gotzeana (dash line) relative abundances. The gray frame highlights the March 7-13 dust event.

the $0.711-0.715$ range, supposedly representing the signatures of local and/or regional contributions. It is noteworthy that the ${ }^{87} \mathrm{Sr} /{ }^{86} \mathrm{Sr}$ ratio in terrigenous sediments is generally sensitive to grain size, with higher ${ }^{87} \mathrm{Sr} /{ }^{86} \mathrm{Sr}$ generally found in smaller size classes [Grousset et al., 1998]. However, the shift in mean modal size of the dust is too subtle to account for the large difference in ${ }^{87} \mathrm{Sr} /{ }^{86} \mathrm{Sr}$ ratio we observe. Thus, the major dust outbreak of March 7-13 can be clearly fingerprinted in ${ }^{87} \mathrm{Sr} /{ }^{86} \mathrm{Sr}$ in addition to changes in clay-minerals assemblages. Taken together, these data imply a shift in dust provenance regions, along with an increased dust flux, during the March event relative to that of the spring of 2006 background period.

\subsection{Change in Dust Provenance Within the Event}

[15] The increased sampling resolution around the March 7-13 outbreak enabled us to document the temporal variability of the terrigenous signal throughout the event. The distinct two phases identified in the atmospheric column by optical data were captured at the ground site at Mbour as well, as readily shown by the dust deposition flux record (Figure 2b). Noticeably, the two stages were accompanied by changes in the nature/characteristics of the dust itself. For instance, the relative abundance of smectite increased from $\sim 34$ to $63 \%$ during the 7 -day event whereas the $\mathrm{I} / \mathrm{K}$ ratio decreased from 0.9 to 0.4 (Figure $5 \mathrm{a}$ and Table 1). The ${ }^{87} \mathrm{Sr}{ }^{86} \mathrm{Sr}$ ratios exhibit a decrease from $\sim 0.720$ during the early phase to $\sim 0.717$ toward the end, while $\varepsilon_{\mathrm{Nd}}$ displayed a moderate change from -13.6 to -13.0 . When plotted against each others, the $\varepsilon_{\mathrm{Nd}}$ and the ${ }^{87} \mathrm{Sr} /{ }^{86} \mathrm{Sr}$ of the three samples collected during the event define a hyperbola (Figure 5b), suggestive of a two-component mixing.

[16] In an attempt to identify the main atmospheric transport patterns and regions of dust activity that led to the large deposition episode at Mbour, tri-dimensional back trajectories were calculated using the HYSPLIT model of NOAA. These back trajectories (Figure 6) show that air masses reaching Mbour during the March 7-13 event swept through Northern Algeria (Atlas region), where the dust storm was initiated. These air masses then progressed across southern Algeria, northern Mali and southeastern Mauritania, that is right through the second most important region of dust emission identified from the Total Ozone Mapping Spectrometer (TOMS) satellite data over the Sahara/Sahel region [Goudie and Middleton, 2001]. This is consistent with Goudie and Middleton's suggestion that the dust transported by the Harmattan from the Bodélé depression in Chad-the most important source area in the world-may not be the source of the prominent winter plume over the Northeastern tropical Atlantic. It is quite apparent, though, that during the event, air mass pathways shifted progressively to the southeast, reaching lower latitudes and longitudes further to the east; indeed, the trajectory ending on March 13 even passes over Northwest Niger (Figure 6). This 

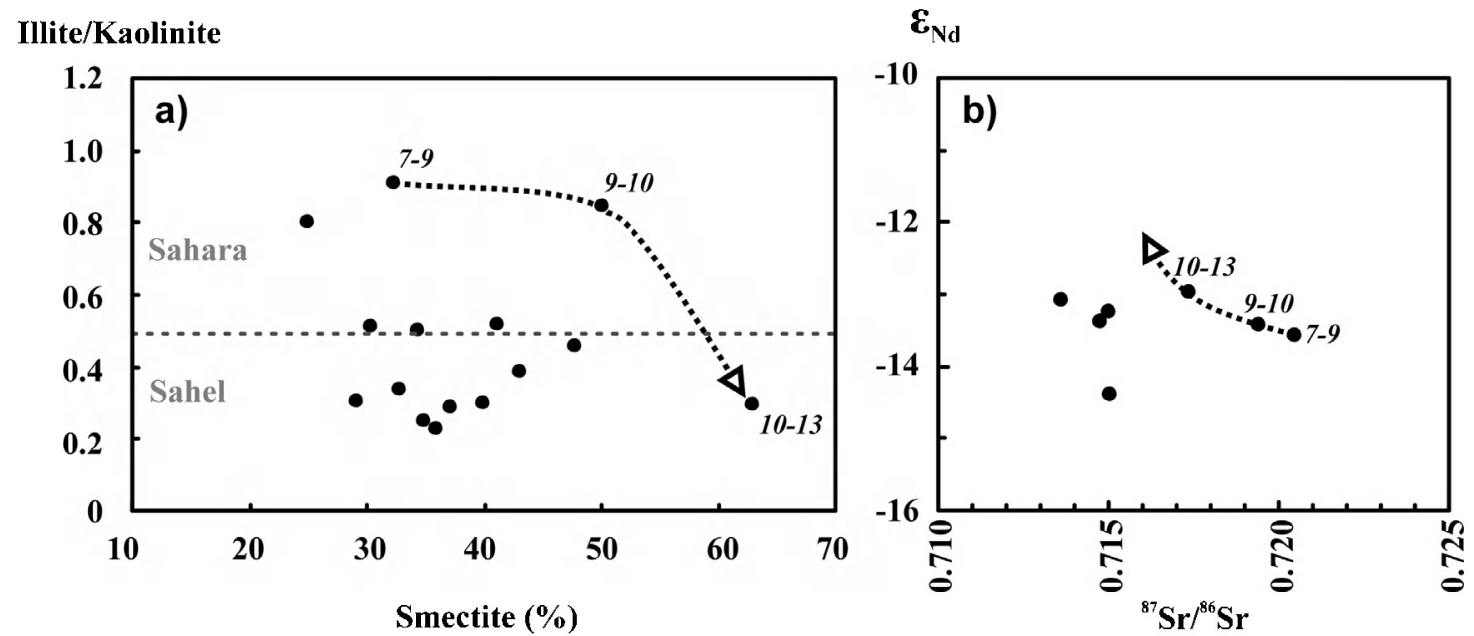

Figure 5. (a) Illite/kaolinite ratio versus smectite content (\%). The dotted line indicates the approximate limit between Saharan and Sahelian I/K values as described by Scheuvens et al. [2009]. (b) $\varepsilon_{\mathrm{Nd}}$ versus ${ }^{87} \mathrm{Sr} /{ }^{86} \mathrm{Sr}$ (error bars less than or equal to symbol size) during the study period. For Figures $5 \mathrm{a}$ and $5 \mathrm{~b}$, samples from the March 7-13 event are labeled with the corresponding sampling dates. Arrows underline the chronological order of the samples.

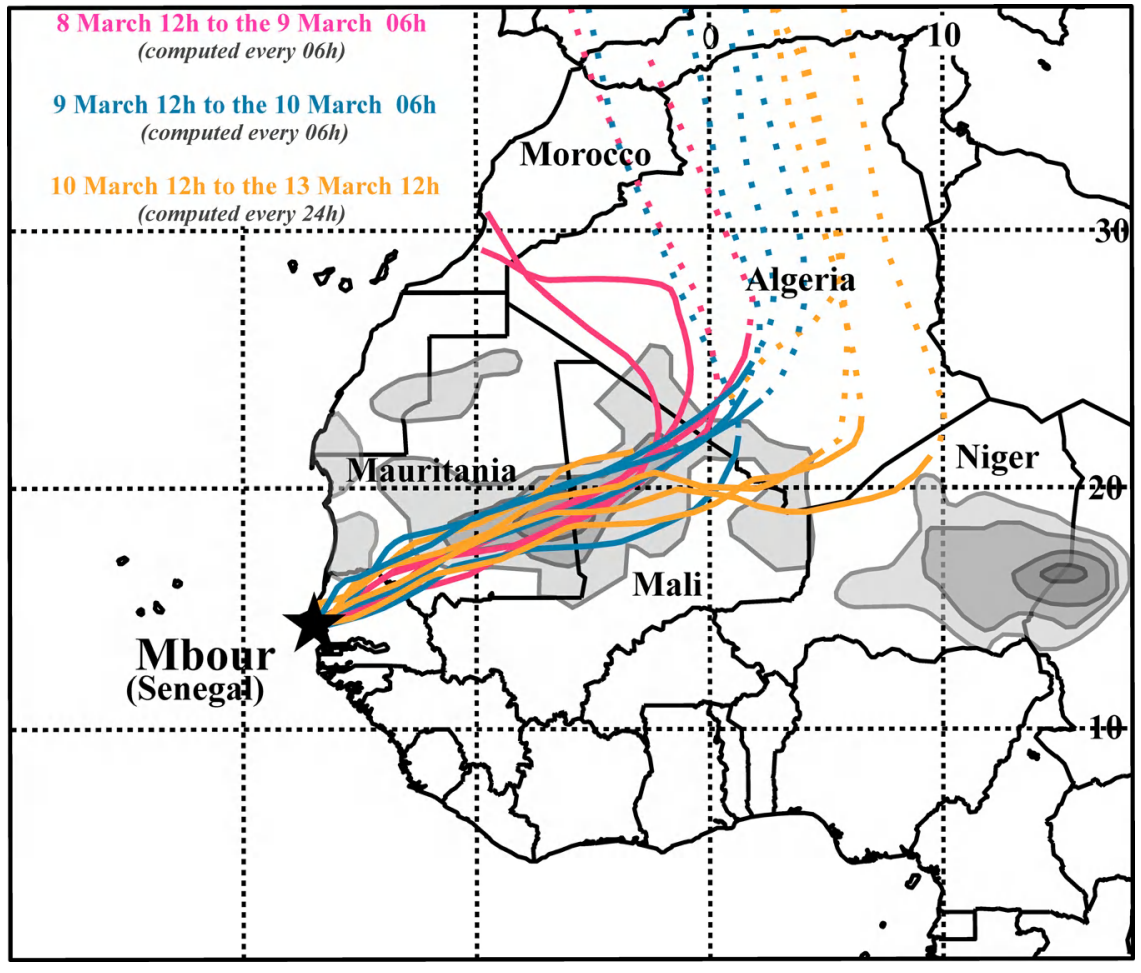

Figure 6. Tri-dimensional air masses back trajectories computed to end at approximately $400 \mathrm{~m} \mathrm{AGL}$ above the Mbour station during the March 7-13 sampling period. Trajectories' duration varies from 3 days at the beginning of the time series to 6 days toward the end (durations were adapted so that trajectories reached the continent's hedges). Air mass latitude higher than $1500 \mathrm{~m}$ (dashed lines) are distinguished from lower transport (solid lines). Calculation was made using the HYSPLIT model (R. R. Draxler and G. D. Rolph, HYSPLIT (HYbrid Single-Particle Lagrangian Integrated Trajectory) Model, 2011, access via NOAA ARL READY Website http:/ready.arl.noaa.gov/HYSPLIT.php; G. D. Rolph, Real-time Environmental Applications and Display system (READY) Website, http://ready.arl.noaa.gov). Background map shows the annual mean Aerosol Index (AI) values $>15$ from TOMS data (1980-93, 1997-2000) (adapted from Goudie and Middleton [2001]). 
observation is in agreement with the change in dust transport direction already identified on MSG/SEVIRI satellite data [Tulet et al., 2008; Marticorena et al., 2010]. In fact, these images show that the initial dust plume, which formed in northern Algeria, first moved southwestward producing further dust emissions along its path before reaching Mbour on March 8. Then, between March 9 and 10, satellite images indicate a change in the direction of the plume, with dust being transported increasingly westward, in a narrower atmospheric corridor sweeping through the Sahelian band.

[17] Clay mineralogy signatures recorded during the March 7-13 event were compared with those of West African soils, loess and aerosols available from the literature. Although chemical and mineralogical fractionations may accompany grain-size sorting during deflation and transport processes, and may thus complicate direct comparison between aerosols and soils/sediments characteristics [Schütz and Sebert, 1987; Sabre et al., 1997], such a comparison supports a southeastern shift in provenance areas supplying dust to Mbour during the event. Specifically, the Western Sahara region is depleted in smectite compared to Sahelian sources [Avila et al., 1997]. Furthermore, the I/K ratio of mineral dust has been shown to decrease overall with decreasing latitude, as well as eastward across the Saharan-Sahelian stretch [Caquineau et al., 2002]. This is consistent with the fact that higher chemical weathering generally results in higher abundances of kaolinite, which mainly forms through hydrolysis processes [Chamley, 1989]. Thus, more kaolinite is expected to be found in the Sahelian band [Caquineau et al., 1998], which was subjected to a higher precipitation regime (summer West African monsoon) during the Quaternary. Southern Saharan and Sahelian regions are thus typified by low $\mathrm{I} / \mathrm{K}$ ratios (typically $<0.5$ ) as well as by particularly low amounts of palygorskite [Scheuvens et al., 2009; Formenti et al., 2010], which both characterize the end of the March 2006 event.

[18] $\mathrm{Sr}$ and $\mathrm{Nd}$ isotope ratios of dust deposited at Mbour during the event fall within the range of values found in the "Sub-Saharan/Sahelian" zone (Chad, Niger, central Mali and Mauritania) defined by Scheuvens et al. [2009]. This author suggested that this area can be further subdivided into a "western" area with higher ${ }^{87} \mathrm{Sr} /{ }^{86} \mathrm{Sr}$ ratios $(>0.720)$ and lower $\varepsilon_{\mathrm{Nd}}$ (around -15), and an "eastern" area with lower ${ }^{87} \mathrm{Sr} /{ }^{86} \mathrm{Sr}$ ratios $(<0.720)$ and higher $\varepsilon_{\mathrm{Nd}}$ values (around -12). This geographical variation in ${ }^{87} \mathrm{Sr} /{ }^{86} \mathrm{Sr}$ and $\varepsilon_{\mathrm{Nd}}$ must largely reflect the fact that the "northwestern" area contains old Precambrian outcrops compared to the "southeastern" area, which is characterized by younger, Paleozoic terrains [Konate et al., 2003]. According to this subdivision, the $\mathrm{Sr}$ and $\mathrm{Nd}$ isotope ratios measured in our samples (Figure $5 \mathrm{~b}$ and Table 1) also support a west-to-east shift within the Sub-Saharan/Sahelian regions that supplied Mbour during the March 2006 event.

[19] Microscopic examination of the fresh-water diatoms in the samples indicates significant changes in the proportions of two taxa, with greater abundances of Hantzshia amphioxys during the early phase and greater occurrences of Aulacoseira granulata/gotzeana during the later phase of the dust event (Figure 4c and Table 1). These two freshwater diatom taxa are usually encountered in deflation basins, wadi valleys or hydrographic paleolakes throughout the Sahara and Sahel [Gasse et al., 1989]. The very low abundances of these diatoms in the dust samples argue for a remote origin. Hantzshia amphioxys, which occurs in various freshwater biotopes, is able to survive subaerial conditions and is common in Northern Mauritania [Gasse et al., 1989]. The other observed taxon, Aulacoseira granulata, is common in lacustrine environments from East Africa [Gasse, 1986]. Changes in diatom dominance thus also corroborate a southeastern migration of the dust deflation zones throughout the dust event.

[20] The changing dust composition that we observe therefore seems to reflect differing mixtures. Dust deposited at Mbour during first phase of the event (March 8-10) likely reflects provenances from the northern and western part of this large Mauritania-Mali-Algeria area. On the other hand, the dust deposited at the end of the event (March 11-13) reflects additional inputs from more southeastern, Sahelian/ sub-Sahara areas. Back trajectories presented here and earlier investigations [Slingo et al., 2006; Thomas and Gautier, 2009], emphasize the fact that major Saharan dust events, such as the March 7-13 outbreak, involve a large geographical domain within which it is unrealistic to accurately pin-point the numerous contributing sources down to a local scale. Nevertheless, our data do show that it is still possible to identify different regional dust signatures associated which changing regional provenance during a major event.

\subsection{Implications}

[21] Major aeolian events, such as the March 7-13 one, are thought to account for most of the total annual dust depositional flux to the ocean [Guerzoni et al., 1997]. For this reason, data obtained in this study provide valuable constraints for developing realistic atmospheric transport models, as well as estimates of dust deposits composition (grain size, mineralogy) and budgets (estimated deposition flux; see Methods for our Capyr-type trap efficiency) for the Western African region. For instance, the comparison of the clay mineralogy of the dust deposited at Mbour during the event shows mismatches with mineralogy modeled from optical measurements for the same event (mainly in terms of clay minerals proportions [Thomas and Gautier, 2009]), underlying the need for field measurements in order to improve model calibrations.

[22] Owing to their significant influx to the ocean, major Saharan-Sahelian dust events have an overriding influence on the terrigenous marine sedimentation in the Northeastern Tropical Atlantic [Rea, 1994]. This conclusion is supported by the ${ }^{87} \mathrm{Sr} /{ }^{86} \mathrm{Sr}$ ratios of the dust deposited during the $7-$ 13 March 2006 outbreak. The corresponding ratios $(0.717-$ 0.720 ; Figure $5 b$ ) overlaps with the $0.718-0.722$ range published for surface sediments, on the similar $<30-40 \mu \mathrm{m}$ size fraction, from the Cape Verde - Canaries Islands latitudinal band in the Northeastern Tropical Atlantic Ocean [Grousset et al., 1998; Cole et al., 2009]. Conversely, the ${ }^{87} \mathrm{Sr} /{ }^{86} \mathrm{Sr}$ ratios found outside the main event $(\sim 0.711-$ 0.715 ), have no counterparts in surface sediments. Therefore, the multiproxy characterization of present-day dust deposited on the Atlantic margin during major events, combined with reliable estimates of dust emission and transport patterns involved, provides essential background information for the interpretation of marine sedimentary records in the Tropical Atlantic. Knowledge of particles provenance is indeed crucial information if we are to 
interpret reliably the terrigenous signal in marine sediments in terms of changes in paleo-environmental conditions in sources areas and/or wind transport patterns.

\section{Conclusion}

[23] Dust deposited at Mbour, Senegal, was sampled during the spring 2006. The 7-13 March 2006 outbreak resulted in a large dust fall, whose mineralogical and $\mathrm{Sr}$ isotopic composition contrast with that of the background signal. Dust compositional changes were also observed between the beginning and the end of the outbreak, with marked differences in clay mineralogy, $\mathrm{Sr}$ and $\mathrm{Nd}$ compositions, and freshwater diatom taxa. Back trajectories and satellite images enabled us to link those distinct signatures to two different provenance regions. These regions lie within the large area identified by Goudie and Middleton [2001] as the main source of the prominent winter/spring plume over the tropical Atlantic - encompassing Mauritania, Mali and southern Algeria and some adjacent areas. Clearly, this survey will need to be repeated to capture other major events and should ideally be extended to other locations on the West African shoreline. Our mineralogical and isotopic fingerprinting of dust provenance and transport systems in West Africa, however, constitutes a first step toward a present-day "calibration" of the dust proxies measured in marine sediment records of the North-Eastern Tropical Atlantic. Since measurements of dust deposition are scarce, the flux and grain size data obtained in this study, among other parameters, provide much needed constraints for atmospheric transport models and dust deposition estimates in this area.

[24] Acknowledgments. We thank the AMMA international scientific group. Detailed information on AMMA scientific coordination and their sources of funding is available at $\mathrm{http}: / \mathrm{www}$.amma-international. org. We are indebted to the IRD-Senegal for granting us access to its Mbour facilities and for technical and logistical support. We gratefully thank all members of the AERONET group, in particular Philippe Goloub and Didier Tanré from the French part of this program (PHOTONS), for operation of the Mbour (Dakar) site. We would like to acknowledge Ingrid Raczek for her precious assistance in the laboratory, Heinz Feldmann for help on the TIMS, Louis Gonzalez for most useful SEVIRI satellite images, Béatrice Marticorena for kindly providing TEOM data and fruitful discussions, and Jean-Louis Rajot for helpful comments on an earlier version of the manuscript. The authors gratefully acknowledge the NOAA Air Resources Laboratory (ARL) for the provision of the HYSPLIT transport and dispersion model and/or READY website (http://www.arl.noaa.gov/ready.php) used in this publication. The manuscript benefited from the helpful comments of two anonymous reviewers.

\section{References}

Arimoto, R. (2001), Eolian dust and climate: Relationships to sources, tropospheric chemistry, transport and deposition, Earth Sci. Rev., 54(1-3) 29-42, doi:10.1016/S0012-8252(01)00040-X.

Avila, A., I. Queralt-Mitjans, and M. Alarcón (1997), Mineralogical composition of African dust delivered by red rains over northeastern Spain, J. Geophys. Res., 102(D18), 21,977-21,996, doi:10.1029/97JD00485.

Biscaye, P. E. (1965), Mineralogy and sedimentation of recent deep-sea clay in the Atlantic Ocean and adjacent seas and oceans, Geol. Soc. Am Bull., 76, 803-832, doi:10.1130/0016-7606(1965)76[803:MASORD] $2.0 . \mathrm{CO} ; 2$.

Bopp, L., K. E. Kohfeld, C. Le Quere, and O. Aumont (2003), Dust impact on marine biota and atmospheric $\mathrm{CO}_{2}$ during glacial periods, Paleoceanography, 18(2), 1046, doi:10.1029/2002PA000810.

Bory, A. J.-M., and P. P. Newton (2000), Transport of airborne lithogenic material down through the water column in two contrasting regions of the eastern subtropical North Atlantic Ocean, Global Biogeochem. Cycles, 14, 297-315, doi:10.1029/1999GB900098.

Bory, A., F. Dulac, C. Moulin, I. Chiapello, P. P. Newton, W. Guelle, C. E. Lambert, and G. Bergametti (2002), Atmospheric and oceanic dust fluxes in the northeastern tropical Atlantic Ocean: How close a coupling?, Ann. Geophys., 20, 2067-2076, doi:10.5194/angeo-20-2067-2002.

Bout-Roumazeilles, V., E. Cortijo, L. Labeyrie, and P. Debrabant (1999), Clay mineral evidence of nepheloid layer contribution to the Henrich layers in the northwest Atlantic, Palaeoclimatol. Palaegeogr. Palaeoecol., 146, 211-228, doi:10.1016/S0031-0182(98)00137-0.

Bout-Roumazeilles, V., N. Combourieu Nebout, O. Peyron, E. Cortijo, A. Landais, and V. Masson-Delmotte (2007), Connection between South Mediterranean climate and North African atmospheric circulation during the last 50,000 yr BP North Atlantic cold events, Quat Sci. Rev., 26, 3197-3215, doi:10.1016/j.quascirev.2007.07.015.

Caquineau, S., A. Gaudichet, L. Gomes, M.-C. Magonthier, and B. Chatenet (1998), Saharan dust: Clay ratio as a relevant tracer to assess the origin of soil-derived aerosols, Geophys. Res. Lett., 25, 983-986, doi:10.1029/ 98GL00569.

Caquineau, S., A. Gaudichet, L. Gomes, and M. Legrand (2002), Mineralogy of Saharan dust transported over northwestern tropical Atlantic Ocean in relation to source regions, $J$. Geophys. Res., 107(D15), 4251, doi:10.1029/2000JD000247.

Chamley, H. (1989), Clay Sedimentology, Springer, Berlin.

Chiapello, I., G. Bergametti, L. Gomes, and B. Chatenet (1995), An additional low layer transport of Sahelian and Saharan dust over the north-eastern tropical Atlantic, Geophys. Res. Lett, 22, 3191-3194, doi:10.1029/95GL03313.

Cole, J. M., et al. (2009), Contrasting compositions of Saharan dust in the eastern Atlantic Ocean during the last deglaciation and African Humid Period, Earth Planet. Sci. Lett., 278(3-4), 257-266, doi:10.1016/j. epsl.2008.12.011.

Derimian, Y., J.-F. Léon, O. Dubovik, I Chiapello, D. Tanré, A. Sinyuk, F. Auriol, T. Podvin, G. Brogniez, and B. N. Holben (2008), Radiative properties of aerosol mixture observed during the dry season 2006 over M'Bour, Senegal (African Monsoon Multidisciplinary Analysis campaign), J. Geophys. Res., I13, D00C09, doi:10.1029/2008JD009904.

Duce, R. A., et al. (1991), The atmospheric input of trace species to the world ocean, Global Biogeochem. Cycles, 5(3), 193-259, doi:10.1029/ 91GB01778.

Formenti, P., L. Schütz, Y. Balkanski, K. Desboeufs, M. Ebert, K. Kandler, A. Petzold, D. Scheuvens, S. Weinbruch, and D. Zhang (2010), Recent progress in understanding physical and chemical properties of mineral dust, Atmos. Chem. Phys. Discuss., 10, 31,187-31,251, doi:10.5194 acpd-10-31187-2010.

Forster, P., et al. (2007), Changes in atmospheric constituents and in radiative forcing, in Climate Change 2007: The Physical Science Basis. Contribution of Working Group I to the Fourth Assessment Report of the Intergovernmental Panel on Climate Change, pp. 129-234, Cambridge Univ. Press, Cambridge, U. K.

Gasse, F. (1986), East African Diatoms: Taxonomy, Ecological Distribution, Biblio. Diatomol, vol. 11, 44 plates, 92 pp., Cramer, Berlin.

Gasse, F., B. Stabell, E. Fourtanier, and Y. van Iperen (1989), Freshwater diatom influx in intertropical Atlantic: Relationships with continental records from Africa, Quat. Res., 32, 229-243, doi:10.1016/0033-5894 (89)90079-3.

Glaccum, R. A., and J. M. Prospero (1980), Saharan aerosols over the tropical North Atlantic mineralogy, Mar. Geol., 37, 295-321, doi:10.1016/ 0025-3227(80)90107-3

Goossens, D., and J.-L. Rajot (2008), Techniques to measure the dry aeolian deposition of dust in arid and semi-arid landscape: A comparative study in West Niger, Earth Surf Processes Landforms, 33, 178-195, doi: $10.1002 /$ esp. 1533 .

Goudie, A. S., and N. J. Middleton (2001), Saharan dust storms: Nature and consequences, Earth Sci. Rev., 56, 179-204, doi:10.1016/S0012$8252(01) 00067-8$

Grousset, F., and P. E. Biscaye (2005), Tracing dust sources and transport patterns using $\mathrm{Sr}, \mathrm{Nd}$, and $\mathrm{Pb}$ isotopes, Chem. Geol, 222, 149-167, doi:10.1016/j.chemgeo.2005.05.006.

Grousset, F. E., M. Parra, A. Bory, P. Martinez, P. Bertrand, G. Shimmield, and R. Ellam (1998), Saharan wind regimes traced by the Sr-Nd isotopic composition of the tropical Atlantic sediments: Last glacial maximum vs. today, Quat. Sci. Rev., 17, 395-409, doi:10.1016/S0277-3791(97)00048-6.

Guerzoni, S., E. Molinaroli, and R. Chester (1997), Saharan dust inputs to the western Mediterranean Sea: Depositional patterns, geochemistry and sedimentological implications, Deep Sea Res., Part II, 44(3-4), 631-654, doi:10.1016/S0967-0645(96)00096-3

Knippertz, P., and A. H. Fink (2006), Synoptic and dynamic aspects of an extreme springtime Saharan dust outbreak, $Q$. J. R. Meteorol. Soc., 132(617), 1153-1177, doi:10.1256/qj.05.109. 
Konate, M., M. Guiraud, J. Lang, and M. Yahaya (2003), Sedimentation in the Kandi extensional basin (Benin and Niger): Fluvial and marine deposits related to the Late Ordovician deglaciation in West Africa, J. Afr. Earth Sci., 36, 185-206, doi:10.1016/S0899-5362(03)00026-5.

Krumbein, W. C., and F. J. Pettijohn (1938), Manual of Sedimentary Petrography, 549 pp., Appleton-Century-Crofts, New York.

Maher, B. A., J. M. Prospero, D. Mackie, D. Gaiero, P. P. Hesse, and Y. Balkanski (2010), Global connections between aeolian dust, climate and ocean biogeochemistry at the present day and at the last glacial maximum, Earth Sci. Rev., 99, 61-97, doi:10.1016/j.earscirev.2009.12.001.

Marticorena, B., B. Chatenet, J.-L. Rajot, S. Traoré, M. Coulibaly, A. Diallo, I. Koné, A. Maman, T. Ndiaye, and A. Zakou (2010), Temporal variability of mineral dust concentrations over West Africa: Analyses of a pluriannual monitoring from the AMMA Sahelian Dust Transect, Atmos. Chem. Phys., 10,8899-8915, doi:10.5194/acp-10-8899-2010.

Martin, J. H., R. M. Gordon, and S. E. Fitzwater (1991), The case for iron, Limnol. Oceanogr., 36(8), 1793-1802, doi:10.4319/lo.1991.36.8.1793.

Meyer, I., G. R. Davies, and J.-B. Stuut (2011), Grain size control on Sr-Nd isotope provenance studies and impact on paleoclimate reconstructions: An example from deep-sea sediments offshore NW Africa, Geochem. Geophys. Geosyst, 12, Q03005, doi:10.1029/2010GC003355.

Prospero, J. M., and T. N. Carlson (1981), Saharan air outbreaks over the tropical North Atlantic, Pure Appl. Geophys., 119(3), 677-691.

Prospero, J. M., P. Ginoux, O. Torres, S. E. Nicholson, and T. E. Gil (2002), Environmental characterization of global sources of atmospheric soil dust identified with the Nimbus 7 Total Ozone Mapping Spectrometer (TOMS) absorbing aerosol product, Rev. Geophys., 40(1), 1002, doi:10.1029/2000RG000095

Rathburn, A. E., J.-J. Pichon, M. A. Ayress, and P. De Deckker (1997) Microfossil and stable-isotope evidence for changes in Late Holocene paleoproductivity and paleoceanographic conditions in the Prydz Bay region of Antarctica, Palaeogeogr. Palaeoclimatol. Palaeoecol., 131 485-510, doi:10.1016/S0031-0182(97)00017-5

Ratmeyer, V., G. Fischer, and G. Wefer (1999), Lithogenic particle fluxes and grain size distributions in the deep ocean off NW Africa: Implications for seasonal changes of aeolian dust input and downward transport, Deep Sea Res., Part I, 46, 1289-1337, doi:10.1016/S0967-0637(99) $00008-4$.

Rea, D. (1994), The paleoclimatic record provided by eolian deposition in the deep sea: The geologic history of wind, Rev. Geophys., 32, 159-195, doi: $10.1029 / 93 \mathrm{RG} 03257$

Redelsperger, J., D. Thorncroft, A. Diedhiou, T. Lebel, D. Parker, and J. Polcher (2006), African Monsoon Multidisciplinary Analysis: An international research project and field campaign, Bull. Am. Meteorol. Soc., 87, 1739-1746, doi:10.1175/BAMS-87-12-1739.

Sabre, M., M. V. López, S. C. Alfaro, J. L. Rajot, and L. Gomes (1997), Characterization of the fine dust particle production process by wind erosion for two types of bare soil surface, in Wind Erosion-An International Symposium [CD-ROM], edited by E. L. Skidmore and J. Tatarko, 11 pp., USDA-ARS Wind Erosion Res. Unit, Manhattan, Kans.

Sassen, K., P. J. DeMott, J. M. Prospero, and M. R. Poellot (2003), Saharan dust storms and indirect aerosol effects on clouds: CRYSTAL-FACE results, Geophys. Res. Lett., 30(12), 1633, doi:10.1029/2003GL017371.
Scheuvens, D., L. Schütz, K. Kandler, M. Ebert, and S. Weinbruch (2009), Composition of Saharan dust and its possible source regions-A review, paper presented at European Aerosol Conference 2009, Assoc. for Aerosol Res., Karlsruhe, Germany.

Schütz, L., and M. Sebert (1987), Mineral aerosols and source identification, J Aerosol Sci., 18, 1-10, doi:10.1016/0021-8502(87)90002-4.

Slingo, A., et al. (2006), Observations of the impact of a major Saharan dust storm on the atmospheric radiation balance, Geophys. Res. Lett., 33, L24817, doi:10.1029/2006GL027869.

Sperazza, M., J. N. Moore, and M. S. Hendrix (2004), High resolution particle size analysis of naturally occurring fine-grained sediment through laser diffractometry, J. Sediment. Res., 74(5), 736-743, doi:10.1306/ 031104740736

Stuut, J.-B., M. Zabel, V. Ratmeyer, P. Helmke, E. Schefuß, G. Lavik, and R. Schneider (2005), Provenance of present-day eolian dust collected off NW Africa, $J$ Geophys. Res., 110, D04202, doi:10.1029/2004JD005161.

Swap, R., S. Ulanski, M. Cobett, and M. Garstand (1996), Temporal and special characteristics of Saharan dust outbreaks, J. Geophys. Res., 10I, 4205-4220, doi:10.1029/95JD03236.

Tegen, I. (2003), Modeling the mineral dust aerosol cycle in the climate system, Quat. Sci. Rev., 22, 1821-1834, doi:10.1016/S0277-3791(03) $00163-\mathrm{X}$.

Thomas, S., and C. Gautier (2009), Investigations of the March 2006 African dust storm using ground-based column-integrated high spectral resolution infrared ( $8-13 \mathrm{~mm}$ ) and visible aerosol optical thickness measurements: 2 . Mineral aerosol mixture analyses, J. Geophys. Res., 114, D14209, doi:10.1029/2008JD010931.

Tulet, P., M. Mallet, V. Pont, J. Pelon, and A. Boone (2008), The 7-13 March 2006 dust storm over West Africa: Generation, transport, and vertical stratification, J. Geophys. Res., 113, D00C08, doi:10.1029/2008JD009871.

W. Abouchami and S. J. G. Galer, Max Planck Institute for Chemistry, PO Box 3060, D-55020 Mainz, Germany.

A. Bory, V. Bout-Roumazeilles, and C. Skonieczny, Geosystemes, FRE CNRS 3298, Université Lille1, F-59655 Villeneuve d'Ascq CEDEX France. (charlotte.skonieczny@ed.univ-lillel.fr)

B. Chatenet, LISA, UMR CNRS 7583, Universités Paris Est-Paris Diderot-Paris 7, IPSL, 61, av. du General de Gaulle, F-94010 Créteil, France.

I. Chiapello and T. Podvin, LOA, UMR CNRS 8518, Université Lille1, F-59655 CEDEX Villeneuve d'Ascq, France.

X. Crosta, EPOC, UMR CNRS 5805, Université Bordeaux1, F-33400 Talence, France.

A. Diallo and T. Ndiaye, IMAGO, US 191, IRD, CP 18524 Dakar, Senegal.

I. Meyer, MARUM, University of Bremen, Leobener Strasse, D-28359 Bremen, Germany.

J.-B. Stuut, Marine Geology, Royal Netherlands Institute for Sea Research, PO Box 59, NL-1790 Den Burg AB, Netherlands. 